\title{
Studies on the Constituents of the Leaves of Morus alba $\mathrm{L}$.
}

\author{
Kayo Doi, ${ }^{a}$ Takashi Kojima, ${ }^{a}$ Mitsuko Makino, ${ }^{b}$ Yumiko Kimura, ${ }^{b}$ and Yasuo Fusimoto ${ }^{*, b}$ \\ Department of Food and Drug, Kanagawa Prefectural Public Health Laboratories, ${ }^{a}$ 1-1-1 Nakao, Asahi-ku, Yokohama \\ 241-0815, Japan and College of Pharmacy, Nihon University, ${ }^{b}$ 7-7-1 Narashinodai, Funabashi, Chiba 274-8555, Japan. \\ Received August 10, 2000; accepted October 20, 2000
}

Two novel prenylflavanes $(1,2)$ and a glycoside $(3)$ of 1 were isolated along with six known compounds, isoquercitrin (4), astragalin (5), scopolin (6), skimmin (7), roseoside II (8) and benzyl D-glucopyranoside (9), from the leaves of Morus alba. The inhibitory activities of compounds 1, 2 and 3 on the oxidation of human low density lipoprotein (LDL) were investigated.

Key words Morus alba; Moraceae; prenylflavane; antioxidative activity

The root bark of Morus alba L. has been used as a blood pressure depressant in China and Japan from old times. The constituents of the root bark were well investigated by T. Nomura $^{1)}$ and $\mathrm{H}$. Hikino's ${ }^{2)}$ groups and many flavones and their derivatives were isolated as active principles. The leaves of this plant have also been used as a blood pressure depressant, but the constituents of the leaves have not yet been thoroughly investigated. We have investigated the pharmacological activities of the leaves of this plant and found that the butanol extracts of the leaves inhibit the increase of serum cholesterol and prevent atherosclerosis. ${ }^{3 a, b)}$ In order to investigate the relationship of the constituents and the pharmacological activities of the leaves, we have studied the constituents of the butanol extracts of mulberry leaves. In this paper, we report the isolation and structural elucidation of two novel prenylflavanes $(\mathbf{1}, \mathbf{2})$ and a glycoside (3) of $\mathbf{1}$ along with six known compounds, isoquercitrin (4), ${ }^{4}$ astragalin $(\mathbf{5}),{ }^{5)}$ scopolin $(\mathbf{6}),{ }^{6}$ skimmin $(7),{ }^{7)}$ roseoside II $(\mathbf{8})^{8)}$ and benzyl D-glucopyranoside (9), ${ }^{9)}$ from the leaves of M. alba.

\section{Results and Discussion}

Compound 1 was obtained as an amorphous powder, $[\alpha]_{\mathrm{D}}$ $-5.5^{\circ}(c=1.0, \mathrm{MeOH})$. Its high resolution EI-MS spectrum showed the [M] ${ }^{+}$ion peak at $\mathrm{m} / \mathrm{z} 340.1684$ corresponding to the molecular formula $\mathrm{C}_{21} \mathrm{H}_{24} \mathrm{O}_{4}(340.1675)$. The ${ }^{1} \mathrm{H}-{ }^{1} \mathrm{H}$ shift correlation spectroscopy (COSY) spectrum of 1 suggested the presence of a prenyl group $[\delta 1.67,1.86(3 \mathrm{H}$ each, br s, H-4", H-5"), $\delta 5.80\left(1 \mathrm{H}\right.$, brt $\left., J=7.3 \mathrm{~Hz}, \mathrm{H}-2^{\prime \prime}\right), \delta 3.85,3.91$ $\left(1 \mathrm{H}\right.$ each, dd, $\left.\left.7.3,13.7 \mathrm{~Hz}, \mathrm{H}-1^{\prime \prime}\right)\right]$, a methoxyl group $[\delta 3.69$ $(3 \mathrm{H}, \mathrm{s})]$, and a sequence of $\mathrm{C}-2-\mathrm{C}-4[\delta 2.71,2.94(1 \mathrm{H}$ each, $\mathrm{m}, \mathrm{H}-4), \delta 2.08,2.42(1 \mathrm{H}$ each, $\mathrm{m}, \mathrm{H}-3), \delta 5.80(1 \mathrm{H}$, dd, $J=2.1,9.5 \mathrm{~Hz}, \mathrm{H}-2)]$, a $1,2,3,4$-tetrasubstituted benzene ring $[\delta 6.84,6.91(1 \mathrm{H}$ each, ABq, $J=8.2 \mathrm{~Hz}, \mathrm{H}-6, \mathrm{H}-5)]$ and a 1,2,4-trisubstituted benzene ring $[\delta 6.66(1 \mathrm{H}, \mathrm{dd}, J=2.4$, $\left.8.5 \mathrm{~Hz}, \mathrm{H}-5^{\prime}\right), \delta 6.85\left(1 \mathrm{H}, \mathrm{d}, J=2.4 \mathrm{~Hz}, \mathrm{H}-3^{\prime}\right), \delta 7.70(1 \mathrm{H}, \mathrm{d}$, $\left.\left.J=8.5 \mathrm{~Hz}, \mathrm{H}-6^{\prime}\right)\right]$.

The substitution pattern on the benzene rings was investigated by the analysis of heteronuclear multiple bond correlation spectroscopy (HMBC) spectrum of $\mathbf{1}$. As shown in Fig. 2 , the methylene proton signal at $\delta 3.85$ and 3.91 (H-1") exhibited long range correlations with the carbon signal at $\delta$ 116.5 (C-8) and two carbon signals $[\delta 155.4(\mathrm{C}-7), \delta 154.7$ (C-8a)] due to oxygen-bearing aromatic carbons, suggesting the presence of a prenyl group at $\mathrm{C}-8$. The proton signals $[\delta$ 2.71, $2.94(1 \mathrm{H}$ each)] due to $\mathrm{H}-4$ showed cross peaks with the carbon signals at $\delta 127.3(\mathrm{C}-5), 113.4(\mathrm{C}-4 \mathrm{a})$, and 154.7 (C-8a). In addition, the H-2 signal at $\delta 5.80$ showed long range correlations with the carbon signals due to $\mathrm{C}-1^{\prime}(\delta$ 122.6), $\mathrm{C}-2^{\prime}(\delta 156.3)$, and $\mathrm{C}-6^{\prime}(\delta 127.9)$ in the trisubstituted benzene ring. Finally, the location of the methoxyl group at C-4' was confirmed by the nuclear Overhauser effect (NOE) experiments on 1. Irradiation at $\delta 3.69$ due to the methoxyl protons produced significant enhancement of proton signals at $\delta 6.85\left(\mathrm{H}-3^{\prime}\right)$ and $\delta 6.66\left(\mathrm{H}-5^{\prime}\right)$ (Fig. 2). The results of the NOE experiments and the spectral data mentioned above was satisfactorily explained by the structure (1) shown in Fig. 2.

Compound 2 was obtained as an amorphous powder, $[\alpha]_{\mathrm{D}}$ $-1.6^{\circ}(c=1.0, \mathrm{MeOH})$. Its CI-MS spectrum showed the $[\mathrm{M}+\mathrm{H}]^{+}$ion peak at $m / z 341$ corresponding to the molecular formula $\mathrm{C}_{21} \mathrm{H}_{25} \mathrm{O}_{4}$. Comparison of the ${ }^{1} \mathrm{H}$ - and ${ }^{13} \mathrm{C}-\mathrm{NMR}$ spectra of $\mathbf{2}$ with those of $\mathbf{1}$ suggested that compound $\mathbf{2}$ is an isomer having the same framework as $\mathbf{1}$ and the structural difference should be the location of a methoxyl group. In the HMBC spectrum of $\mathbf{2}$, the methoxyl proton signal at $\delta 3.74$ showed a cross peak with the carbon signal at $\delta 157.0$ (C-7) which exhibited long range couplings with the proton signals at $\delta 3.63-3.74\left(\mathrm{H}-1^{\prime \prime}\right)$ assignable to the methylene protons of a prenyl group. Furthermore, in the difference NOE experiments, irradiation of the methoxyl proton signal produced significant enhancement of the proton signal at $\delta 6.57$ due to

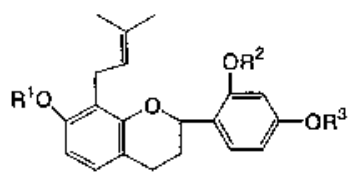

(1): $\mathrm{R}^{1}=\mathrm{R}^{2}=\mathrm{H}_{r} \mathrm{R}^{3}=\mathrm{CH}_{3}$ (2): $\mathrm{R}^{\mathrm{l}}=\mathrm{CH}_{3}, \mathrm{R}^{2}=\mathrm{R}^{3}=\mathrm{H}$ (3): $\mathrm{R}^{1}=\mathrm{R}^{2}=\mathrm{Gla}, \mathrm{R}^{3}=\mathrm{CH}_{3}$

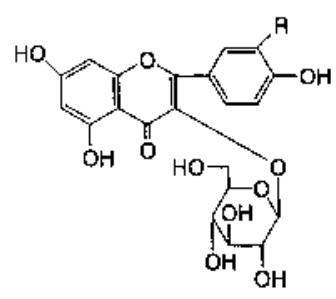

isogyercition (4); $\mathrm{R}=\mathrm{OH}$ astragalis $(5): \mathrm{R}=\mathrm{H}$
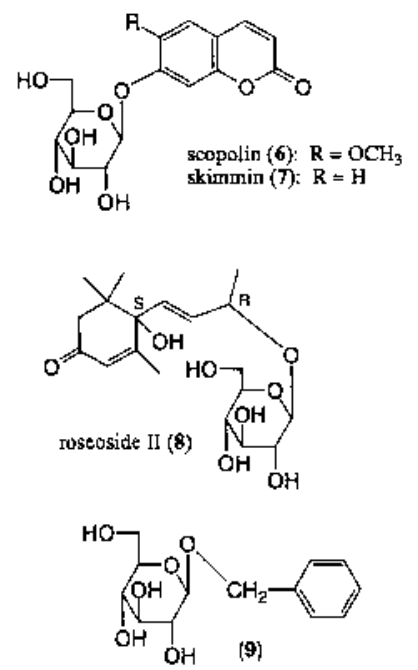

Fig. 1

(C) 2001 Pharmaceutical Society of Japan 


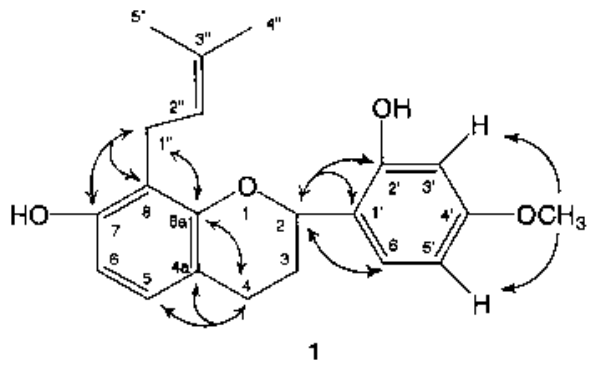

Fig. 2. Selected $\operatorname{HMBC}(\hookrightarrow)$ and $\operatorname{NOE}(\longrightarrow)$ on $\mathbf{1}$

Table 1. ${ }^{1} \mathrm{H}-\mathrm{NMR}\left(500 \mathrm{MHz}, \delta, \mathrm{C}_{5} \mathrm{D}_{5} \mathrm{~N}\right)$ Data for $\mathbf{1}, \mathbf{2}$, and $\mathbf{3}$

\begin{tabular}{|c|c|c|c|}
\hline Position & 1 & 2 & 3 \\
\hline 2 & $5.80 \mathrm{dd}(2.1,9.5)$ & $5.84 \mathrm{dd}(2.4,9.5)$ & $5.79 \mathrm{dd}(2.2,9.8)$ \\
\hline \multirow[t]{2}{*}{3} & $2.08 \mathrm{~m}$ & $2.14 \mathrm{~m}$ & $1.89 \mathrm{~m}$ \\
\hline & $2.42 \mathrm{~m}$ & $2.43 \mathrm{~m}$ & $2.29 \mathrm{~m}$ \\
\hline \multirow[t]{2}{*}{4} & $2.71 \mathrm{~m}$ & $2.82 \mathrm{~m}$ & $2.51 \mathrm{~m}$ \\
\hline & $2.94 \mathrm{~m}$ & $2.99 \mathrm{~m}$ & $2.67 \mathrm{~m}$ \\
\hline 5 & $6.91 \mathrm{~d}(8.2)$ & $6.96 \mathrm{~d}(8.5)$ & $6.82 \mathrm{~d}(8.2)$ \\
\hline 6 & $6.84 \mathrm{~d}(8.2)$ & $6.57 \mathrm{~d}(8.5)$ & $7.21 \mathrm{~d}(8.2)$ \\
\hline $3^{\prime}$ & $6.85 \mathrm{~d}(2.4)$ & $6.97 \mathrm{~d}(2.4)$ & $7.32 \mathrm{~d}(2.4)$ \\
\hline $5^{\prime}$ & $6.66 \mathrm{dd}(2.4,8.5)$ & $6.88 \mathrm{dd}(2.4,8.2)$ & $6.80 \mathrm{dd}(2.4,8.5)$ \\
\hline $6^{\prime}$ & $7.70 \mathrm{~d}(8.5)$ & $7.67 \mathrm{~d}(8.2)$ & $7.67 \mathrm{~d}(8.5)$ \\
\hline \multirow[t]{2}{*}{$1^{\prime \prime}$} & $3.85 \mathrm{dd}(7.3,13.7)$ & $3.63-3.74 \mathrm{~m}$ & $3.70 \mathrm{dd}(7.3,13.4)$ \\
\hline & $3.91 \mathrm{dd}(7.3,13.7)$ & & 3.95 dd $(7.3,13.4)$ \\
\hline $2^{\prime \prime}$ & $5.80 \mathrm{brt}(7.3)$ & 5.62 brt (7.3) & 5.73 brt (7.3) \\
\hline $4^{\prime \prime}$ & $1.67 \mathrm{brs}$ & $1.63 \mathrm{brs}$ & $1.64 \mathrm{brs}$ \\
\hline $5^{\prime \prime}$ & 1.86 br s & 1.80 br s & 1.78 br s \\
\hline $\mathrm{OCH}_{3}$ & $3.69 \mathrm{~s}$ & $3.74 \mathrm{~s}$ & $3.72 \mathrm{~s}$ \\
\hline \multicolumn{4}{|l|}{ 7-O-Glc } \\
\hline \multicolumn{4}{|r|}{$5.59 \mathrm{~d}(7.3)$} \\
\hline \multicolumn{4}{|l|}{ Glc-2 } \\
\hline Glc-3 & & & $4.32-4.36$ \\
\hline \multicolumn{4}{|l|}{ Glc-4 } \\
\hline Glc-5 & & & $4.10 \mathrm{~m}$ \\
\hline \multirow[t]{2}{*}{ Glc-6 } & & & $4.39 \mathrm{dd}(5.2,11.9)$ \\
\hline & & & $4.57 \mathrm{dd}(2.7,11.9)$ \\
\hline \multicolumn{4}{|l|}{ 2'-O-Glc } \\
\hline \multicolumn{4}{|r|}{$5.54 \mathrm{~d}(7.3)$} \\
\hline \multicolumn{4}{|l|}{ Glc-2 } \\
\hline Glc-3 & & & $4.27-4.32$ \\
\hline \multicolumn{4}{|l|}{ Glc-4 } \\
\hline Glc-5 & & & $4.09 \mathrm{~m}$ \\
\hline \multirow[t]{2}{*}{ Glc-6 } & & & $4.36 \mathrm{dd}(5.2,11.6)$ \\
\hline & & & $4.55 \mathrm{dd}(2.5,11.6)$ \\
\hline
\end{tabular}

The numbers in parentheses are $J$ values in $\mathrm{Hz}$.

H-6. Thus, the structure of $\mathbf{2}$ was confirmed as shown in Fig. 1.

Compound 3 was obtained as an amorphous powder, $[\alpha]_{\mathrm{D}}$ $-91.1^{\circ}(c=0.25, \mathrm{MeOH})$. Its FAB-MS spectrum showed the $[\mathrm{M}+\mathrm{Na}]^{+}$ion peak at $\mathrm{m} / \mathrm{z} 687$ corresponding to the molecular formula $\mathrm{C}_{33} \mathrm{H}_{44} \mathrm{O}_{14} \mathrm{Na}$. Detailed analyses of the ${ }^{1} \mathrm{H}$ - and ${ }^{13} \mathrm{C}$-NMR spectra of $\mathbf{3}$ suggested that $\mathbf{3}$ must be a glycoside of $\mathbf{1}$ (see Tables 1 and 2). Enzymatic hydrolysis of $\mathbf{3}$ with $\beta$ D-glucosidase gave D-glucose and $\mathbf{1}$. The nuclear Overhauser enhancement spectroscopy (NOESY) spectrum of $\mathbf{3}$ exhibited cross peaks between the following proton signals; $\delta 7.32$ $\left(\mathrm{H}-3^{\prime}\right)$ and $\delta 5.54\left(\mathrm{H}-1\right.$ of $2^{\prime}$-O-Glc); $\delta 7.21(\mathrm{H}-6)$ and $\delta$ 5.59 (H-1 of 7-O-Glc); $\delta 3.72\left(\mathrm{CH}_{3} \mathrm{O}-4^{\prime}\right)$ and $\delta 6.80\left(\mathrm{H}-5^{\prime}\right)$. Furthermore, long-range correlations were observed between the signals at $\delta 5.54\left(\mathrm{H}-1\right.$ of $\left.2^{\prime}-\mathrm{O}-\mathrm{Glc}\right)$ and d $155.9\left(\mathrm{C}-2^{\prime}\right)$, and the signals at $\delta 5.59$ (H-1 of 7-O-Glc) and $\delta 155.7$ (C-7)
Table 2. ${ }^{13} \mathrm{C}-\mathrm{NMR}\left(125 \mathrm{MHz}, \delta, \mathrm{C}_{5} \mathrm{D}_{5} \mathrm{~N}\right)$ Data for $\mathbf{1}, \mathbf{2}$, and $\mathbf{3}$

\begin{tabular}{|c|c|c|c|}
\hline Position & 1 & 2 & 3 \\
\hline 2 & 73.5 & 73.8 & 72.8 \\
\hline 3 & 29.3 & 29.3 & 29.8 \\
\hline 4 & 26.0 & 25.4 & 25.2 \\
\hline $4 a$ & 113.4 & 115.4 & 116.3 \\
\hline 5 & 127.3 & 127.3 & 127.4 \\
\hline 6 & 108.3 & 103.6 & 108.4 \\
\hline 7 & 155.4 & 157.0 & 155.7 \\
\hline 8 & 116.5 & 117.6 & 119.3 \\
\hline $8 \mathrm{a}$ & 154.7 & 154.4 & 154.1 \\
\hline $1^{\prime}$ & 122.6 & 120.7 & 124.5 \\
\hline $2^{\prime}$ & 156.3 & 156.6 & 155.9 \\
\hline $3^{\prime}$ & 102.3 & 103.7 & 102.6 \\
\hline $4^{\prime}$ & 160.5 & 159.5 & 160.7 \\
\hline $5^{\prime}$ & 104.7 & 107.5 & 108.0 \\
\hline $6^{\prime}$ & 127.9 & 128.1 & 127.4 \\
\hline $1^{\prime \prime}$ & 23.3 & 23.0 & 23.3 \\
\hline $2^{\prime \prime}$ & 124.8 & 124.3 & 124.5 \\
\hline $3^{\prime \prime}$ & 130.2 & 130.5 & 130.5 \\
\hline $4^{\prime \prime}$ & 26.0 & 25.9 & 25.9 \\
\hline $5^{\prime \prime}$ & 18.2 & 18.0 & 18.2 \\
\hline $\mathrm{OCH}_{3}$ & 55.1 & 55.8 & 55.3 \\
\hline \multicolumn{4}{|l|}{ 7-O-Glc } \\
\hline Glc-1 & & & 103.5 \\
\hline Glc-2 & & & 75.2 \\
\hline Glc-3 & & & 78.9 \\
\hline Glc-4 & & & 71.5 \\
\hline Glc-5 & & & 79.0 \\
\hline Glc-6 & & & 62.6 \\
\hline \multicolumn{4}{|l|}{$2^{\prime}-\mathrm{O}-\mathrm{Glc}$} \\
\hline Glc-1 & & & 103.0 \\
\hline Glc-2 & & & 75.0 \\
\hline Glc-3 & & & 78.7 \\
\hline Glc-4 & & & 71.4 \\
\hline Glc-5 & & & 78.8 \\
\hline Glc-6 & & & 62.5 \\
\hline
\end{tabular}

Table 3. Inhibitory Effects of $\mathbf{1}, \mathbf{2}$, and $\mathbf{3}$ on Lag Time for $\mathrm{CuSO}_{4}$-Induced Oxidation of Human LDL by Continuous Monitoring of Conjugated Diene Formation

\begin{tabular}{cccc}
\hline \hline Sample & Concentration & $n$ & Relative lag time $^{a)}$ \\
\hline Quercetin & $0.5 \mathrm{nmol} / \mathrm{ml}$ & 5 & 1.00 \\
$\mathbf{1}$ & $0.5 \mathrm{nmol} / \mathrm{ml}$ & 4 & $1.70 \pm 0.25$ \\
$\mathbf{2}$ & $0.5 \mathrm{nmol} / \mathrm{ml}$ & 4 & $0.81 \pm 0.10$ \\
$\mathbf{3}$ & $10.0 \mathrm{nmol} / \mathrm{ml}$ & 3 & $0.85 \pm 0.07$ \\
\hline
\end{tabular}

Values are means+S.D. a) Values are relative to the lag time of $0.5 \mathrm{nmol} / \mathrm{ml}$ quercetin assigned an arbitrary value of 1.0 .

in the HMBC spectrum of $\mathbf{3}$. Thus, the structure of $\mathbf{3}$ was confirmed as the 2',7-di- $O$-glucoside of $\mathbf{1}$.

Antioxidative Activities of New Compounds We have reported that the butanol extracts of mulberry leaves and its major component, isoquercitrin, exhibited inhibitory activity on $\mathrm{CuSO}_{4}$-induced oxidation of low density lipoprotein (LDL) and scavenging activity on 1,1-diphenyl-2-picrylhydrazyl (DPPH) radical. ${ }^{10)}$ We examined the antioxidative effects and radical scavenging activities of compounds $\mathbf{1}, \mathbf{2}$ and 3 on human LDL and DPPH radical. As shown in Table 3, 1 showed stronger antioxidative activity than quercetin used as a positive control, while 2 exhibited almost the same activity as that of quercetin. On the other hand, both $\mathbf{1}$ and $\mathbf{2}$ exhibited very weak radical scavenging activity (Table 4). As expected, glycoside (3) showed hardly any antioxidative activi- 
Table 4. Scavenging Effects of 1, 2, and $\mathbf{3}$ on DPPH Radical

\begin{tabular}{cc}
\hline \hline Sample & $\mathrm{IC}_{50}(\mathrm{nmol} / \mathrm{ml})$ \\
\hline Quercetin & 3.7 \\
$\mathbf{1}$ & 137 \\
$\mathbf{2}$ & 603 \\
$\mathbf{3}$ & 505 \\
\hline
\end{tabular}

ties or radical scavenging effect.

\section{Experimental}

The leaves of Morus alba L. were collected in Kanagawa prefecture and dried at $60-80^{\circ} \mathrm{C}$ for $95 \mathrm{~min}$ with a tea manufacturing machine. The ${ }^{1} \mathrm{H}$ and ${ }^{13} \mathrm{C}$-NMR spectra were measured on a JEOL JNM-Lambda-500 spectrometer in $\mathrm{CDCl}_{3}$ containing TMS as internal standard. The MS spectra were recorded on a Hitachi RMU-6M instrument. Optical rotation was measured on a JASCO DIP-370 polarimeter.

Isolation of Compounds $1-9$ The dried leaves $(2 \mathrm{~kg})$ were extracted with hexane $(21 \times 3)$ and then 1-butanol $(11 \times 3)$. The 1-butanol solution was washed with water $(500 \mathrm{ml} \times 3)$ and then concentrated at $40^{\circ} \mathrm{C}$ under reduced pressure to give an oily material $(80 \mathrm{~g})$ which was chromatographed on a Diaion HP-20 column eluted successively with 1.51 each of $\mathrm{H}_{2} \mathrm{O}, 20 \%$ $\mathrm{MeOH}, 30 \% \mathrm{MeOH}, 40 \% \mathrm{MeOH}, 60 \% \mathrm{MeOH}, 80 \% \mathrm{MeOH}, \mathrm{MeOH}$ and then acetone to afford eight fractions [fr. $1(3.83 \mathrm{~g})$, fr. $2(1.75 \mathrm{~g})$, fr. 3 $(1.03 \mathrm{~g})$, fr. $4(1.90 \mathrm{~g})$, fr. $5(1.65 \mathrm{~g})$, fr. $6(0.74 \mathrm{~g})$, fr. $7(3.0 \mathrm{~g})$, fr. $8(1.82 \mathrm{~g})]$. The fr. 2 was separated into two fractions [fr. $2-1(1.57 \mathrm{~g})$, fr. $2-2(0.17 \mathrm{~g})]$ by Sephadex LH 20 column chromatography $\left[\mathrm{H}_{2} \mathrm{O}-\mathrm{MeOH}\right.$, gradient with increasing of $\mathrm{MeOH}]$. The fr. 2-1 was further separated by reversed phase HPLC [Inertsil prep ODS (GL Science Ltd.), $20 \times 250 \mathrm{~mm}$ (column 1), $\left.\mathrm{H}_{2} \mathrm{O}-\mathrm{MeOH}(68: 32)\right]$ to give five fractions [fr. 2-1-1 $(0.16 \mathrm{~g})$, fr. $2-1-2$ $(0.27$ g), fr. $2-1-3(0.08$ g), fr. 2-1-4 (0.42 g), fr. 2-1-5 (0.58 g)]. The fr. 2-1-2 was purified by reversed phase HPLC [Column $\left.1, \mathrm{H}_{2} \mathrm{O}-\mathrm{MeOH}(73: 27)\right]$ to give scopolin $(6,7 \mathrm{mg})$ and skimmin $(7,25 \mathrm{mg})$. Purification of the fr. 2-1-4 by reversed phase HPLC [column $1, \mathrm{H}_{2} \mathrm{O}-\mathrm{MeOH}(3: 1)$ ] gave benzyl alcohol glucopyranoside $(9,15 \mathrm{mg})$. The fr. 2-1-5 was separated into four fractions (fr. 2-1-5-1, fr. 2-1-5-2, fr. 2-1-5-3, fr. 2-1-5-4) by reversed phase column chromatography [Wakogel RP 18, stepwise gradients of $\mathrm{H}_{2} \mathrm{O}_{2} \mathrm{H}_{2} \mathrm{O}-$ $\mathrm{MeOH}(2: 1$ and $1: 1)$ and $\mathrm{MeOH}]$ and then fr. 2-1-5-2 was further purified by reversed phase HPLC [Mightysil ODS (Kantokagaku Ltd.), $20 \times 300 \mathrm{~mm}$ (column 2), $\mathrm{H}_{2} \mathrm{O}-\mathrm{MeOH}(77: 23)$ ] to give roseoside II $(\mathbf{8}, 24 \mathrm{mg})$. The fr. 4 was separated into four fractions [fr. 4-1 $(0.69 \mathrm{~g})$, fr. $4-2(0.51 \mathrm{~g})$, fr. 4-3 $(0.43 \mathrm{~g})$, fr. $4-4(0.28 \mathrm{~g})$ ] by reversed phase HPLC [column 1 , stepwise gradients of $\mathrm{H}_{2} \mathrm{O}-\mathrm{MeOH}(7: 3$ and $2: 3)$ and $\mathrm{MeOH}$ ]. The fr. 4-2 was recrystallized from $\mathrm{MeOH}$ to give isoquercitrin $(4,360 \mathrm{mg})$. Further separation of the fr. 4-3 by reversed phase HPLC [column 1 , stepwise gradients of $\mathrm{H}_{2} \mathrm{O}-$ $\mathrm{MeOH}(3: 1$ and $2: 3)]$ afforded astragalin $(5,212 \mathrm{mg})$. The fr. 5 was separated by reversed phase HPLC [column $2, \mathrm{H}_{2} \mathrm{O}-\mathrm{MeOH}(44: 55)$, flow rate; $10 \mathrm{ml} / \mathrm{min}$ ] to give two fractions [fr. 5-1 (retention time, $9.0 \mathrm{~min}$ ), fr. 5-2 (retention time, $15.0 \mathrm{~min})]$. The fr. $5-2$ was further purified by reversed phase HPLC [column $1, \mathrm{H}_{2} \mathrm{O}-\mathrm{MeOH}(49: 51)$, flow rate; $9.0 \mathrm{ml} / \mathrm{min}$ ] to afford 3 ( $25 \mathrm{mg}$, retention time, $39 \mathrm{~min}$ ). The fr. 7 was separated by reversed phase HPLC [column 2, $\mathrm{H}_{2} \mathrm{O}-\mathrm{MeOH}(20: 80)$, flow rate; $7.0 \mathrm{ml} / \mathrm{min}$ ] to give two fractions [fr. 7-1 (retention time, $16.0 \mathrm{~min}$ ), fr. 7-2 (retention time, $23.0 \mathrm{~min}$ )]. The fr. 7-1 was further purified by reversed phase HPLC [Inertsil prep ODS (GL Science Ltd.), $10 \times 250 \mathrm{~mm}$ (column 3), $\mathrm{H}_{2} \mathrm{O}-\mathrm{MeOH}(28: 72)$, flow rate; $5.0 \mathrm{ml} / \mathrm{min}$ ] to afford 1 ( $35 \mathrm{mg}$, retention time, $8.0 \mathrm{~min})$. The fr. 7-2 was further purified by reversed phase HPLC [column $3, \mathrm{H}_{2} \mathrm{O}-\mathrm{MeOH}(25: 75)$, flow rate; $5.0 \mathrm{ml} / \mathrm{min}$ ] to afford $2(6 \mathrm{mg}$, retention time, $12.0 \mathrm{~min})$.

Enzymatic Hydrolysis of Compound 3 Compound $3(1.0 \mathrm{mg})$ was dissolved in $\mathrm{H}_{2} \mathrm{O}(0.2 \mathrm{ml})$ with $\beta$-D-glucosidase $(1.0 \mathrm{mg})$ (Oriental Yeast Co. Ltd., $10000 \mathrm{U} / 271.8 \mathrm{mg}$ ) and incubated at $40^{\circ} \mathrm{C}$ for $4 \mathrm{~h}$. The mixture was extracted with ethyl acetate and then the organic layer and the water layer were concentrated in vacuo, respectively. From the ethyl acetate extract, compound 1 was identified by direct comparison with an authentic sample on
TLC. $R f 0.60$ ( $n$-hexane : AcOEt=1:1). From the water layer residue, D-glucose was identified by TLC direct comparison with an authentic sample. $R f$ 0.43 ( $\left.n-\mathrm{BuOH}: \mathrm{Me}_{2} \mathrm{CO}: \mathrm{H}_{2} \mathrm{O}=4: 5: 1\right)$. Acid hydrolysis of 3 with $1 \mathrm{~N} \mathrm{HCl}$ $\left(110^{\circ} \mathrm{C}, 1 \mathrm{~h}\right)$ gave $\mathrm{D}-$ glucose, but compound 1 was not detected from the reaction mixture because of degradation of the aglycon during hydrolysis.

Assay for Antioxidative and Radical Scavenging Activities

Materials Quercetin dehydrate was purchased from Extrasynthese (France). Disodium ethylenediaminetetraacetate (EDTA-2Na), butylated hydroxytoluene, copper sulfate, sodium azide and diisopropyl fluorophosphate (DFP) were purchased from Wako Pure Chemical Industries (Osaka, Japan).

Isolation of Human LDL ${ }^{11)}$ Plasma was obtained after low-speed centrifugation of fresh blood collected in the presence of EDTA-2Na $(0.2 \mathrm{M})$ and stored at $-20^{\circ} \mathrm{C}$ before use. Human LDL was isolated from plasma by preparative ultracentrifugation using Beckman model L-70 in a Beckman type $70.1 \mathrm{Ti}$ rotor. The protein content in the LDL was measured by using a BCA protein kit (Pierce, IL, U.S.A.) and LDL concentration is expressed as protein content. The LDL was stored at $4{ }^{\circ} \mathrm{C}$ for later use. Human LDL was dialyzed three times in $24 \mathrm{~h}$ at $4{ }^{\circ} \mathrm{C}$ by a 100 fold volume of $10 \mathrm{~mm}$ deoxygenated phosphate buffer containing $0.16 \mathrm{~m}$ sodium chloride (PBS, $\mathrm{pH} 7.4$ ) to remove EDTA-2Na.

Continuous Monitoring of Conjugated Diene Formation from LDL Dialyzed LDL was diluted to $2.05 \mathrm{mg}$ protein $/ \mathrm{ml}$ with $10 \mathrm{~mm}$ PBS. Conjugated diene formation during oxidation of LDL was continuously monitored by the spectrophotometric method, ${ }^{12)}$ which is based on measurement of change in absorbance at $234 \mathrm{~nm}$. The concentrations of LDL and copper were $0.05 \mathrm{mg} / \mathrm{ml}$ and $1.66 \mu \mathrm{M}$, respectively. Oxidation was initiated by addition of freshly prepared aqueous $\mathrm{CuSO}_{4}$ solution at $37^{\circ} \mathrm{C}$ (final concentration: $1.66 \mu \mathrm{M})$ in the absence or presence of sample and continuously monitored by the absorbance at $234 \mathrm{~nm}$ using a Hitachi spectrophotometer (Tokyo, Japan).

Colorimetric Determination of the Scavenging Effect of Substances on DPPH Radical The scavenging effect of each substance on DPPH radical was measured by monitoring the decrease in absorbance at $517 \mathrm{~nm} .{ }^{13)}$ The ethanol solution $(1 \mathrm{ml})$ of each sample was added to $0.5 \mathrm{ml}$ of $200 \mu \mathrm{M}$ ethanol solution of DPPH (final concentration of DPPH: $40 \mu \mathrm{M}$ ). After mixing for $10 \mathrm{~s}$ on a vortex mixer, the solution was allowed to stand for $30 \mathrm{~min}$ and the absorbance of the resulting solution at $517 \mathrm{~nm}$ was measured. The scavenging activity on DPPH radical was expressed as $\mathrm{EC}_{50}$.

\section{References}

1) Nomura T., "Progress in the Chemistry of Organic Natutrl Products," Vol. 53, Springer-Verlag, New York, 1988, pp. 87-201.

2) Oshima Y., Konno C., Hikino H., Matsushita K., Heterocycles, 14, 1287-1290 (1980).

3) a) Doi K., Kojima T., Harada M., Horiguchi Y., Nippon Eiyo Shokuryo Gakkaishi, 47, 15-22 (1994); b) Doi K., Kojima T., Harada M., Horiguchi Y., Fujimoto Y., ibid., 52, 85-90 (1999).

4) Takagi S., Yamaki M., Masuda K., Nishihama M., Kubota M., Lu S. T., Yakugaku Zasshi, 101, 482-484 (1981).

5) Takagi S., Yamaki M., Masuda K., Kubota M., Yakugaku Zasshi, 97, 1369-1371 (1977).

6) Tsukamoto H., Hisada S., Nishibe S., Chem. Pharm. Bull., 33, 396399 (1985).

7) Austin D. J., Meyers M. B., Phytochemistry, 4, 255-262 (1965).

8) Otsuka H., Yao M., Kamada K., Takeda Y., Chem. Pharm. Bull., 43, 754-759 (1995).

9) Itogawa H., Oshida Y., Ikuta A., Inatomi H., Adachi T., Phytochemistry, 21, 1935-1937 (1982).

10) Doi K., Kojima T., Fujimoto Y., Biol. Pharm. Bull., 23, 1066-1071 (2000).

11) Hatch F. T., Less R. S., Adv. Lipid. Res., 6, 1-68 (1968).

12) Esterbauer H., Striegl G., Puhl H., Rotheneder M., Free Radical Res. Commns, 6, 67-75 (1989).

13) Braude E. A., Brook A. G., Linstead R. P., J. Chem. Soc., 1954, 3574-3578. 